\title{
水滴の蒸発速度を利用したスケールを有する鋼板表面からの 抜熱流束の評価
}

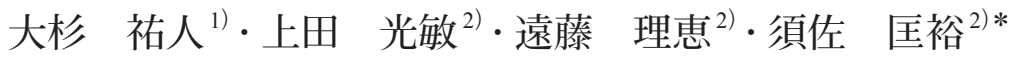

Evaluation of Heat Flux Extracted from Steel Surface with Oxide Scale Utilizing Evaporation Rate of Water Droplet

Yuto Ohsugi, Mitsutoshi Ueda, Rie Endo and Masahiro SusA

Synopsis : The present work has proposed a new method to evaluate heat flux extracted from steel surface with iron oxide scale using the mass change of a water droplet and the standard enthalpy of evaporation for water at $100^{\circ} \mathrm{C}$. The apparatus was composed of a furnace, an electronic balance, a water droplet supplying device, a combination of a thermocouple and a digital multi-meter, in addition to a video camera. Ultra-low carbon steel plate samples were oxidised in air at $850^{\circ} \mathrm{C}$ in the furnace so as to have iron oxide scale (mainly $\mathrm{FeO}$ ) with desired thicknesses, and then moved onto the electronic balance. About $3 \mathrm{~g}$ of water was supplied onto the sample, and the mass change of water and temperature inside the sample were measured by the balance and the thermocouple, respectively. In addition, boiling behaviour of water was also recorded by the video camera. The mass and temperature changes well corresponded to the video images which recorded film boiling and nucleate boiling of water. The quench temperatures obtained in experiments using the samples with scales 40, 58, 77 and $103 \mu \mathrm{m}$ thick were 131, 167, 121 and $182^{\circ} \mathrm{C}$, respectively, and the respective heat fluxes just before quench were estimated to be $31,35,33$ and $43 \mathrm{kWm}^{-2}$. Assuming that the present system is at a quasi-steady state, Fourier's law has been applied to estimate the thickness of water vapour film during film boiling; resultantly, the thickness decreases from $c a 100 \mu \mathrm{m}$ to $c a 20 \mu \mathrm{m}$ with cooling of steel.

Key words : iron oxide scale; droplet film boiling; evaporation rate; extracted heat flux; vapour film thickness.

\section{1. 緒言}

鉄鋼生産プロセスにおいて，所定の材質を有する鋼板を 製造するためには，熱延プロセス後の水スプレーなどによ る冷却を㛜密に制御し，均一に冷却することが非常に重要 である ${ }^{1)}$ 。鋼板は高温の状態で空気中を搬送されるために， その表面には酸化スケールが生成する。このスケールは高 圧水により何度も除去されるが，鋼は高温で容易に酸化す るために，仕上げ圧延後に打いても数 $10 \mu \mathrm{m}$ 厚のスケール が存在する。すなわち，水冷却プロセスでは，鋼板からの 抜熱はスケールを介して行われることとなる。問題は，そ のスケールの厚さが場所によって異なることであり，それ が鋼材冷却の不均一を招く一因となっている。この不均一 な冷却により, 鋼板内部に残留応力が発生して加工後の変 形に繋がり，さらに鋼表面に混在する硬さの違う相が圧延 時の表面疵や圧延ロールの劣化を招く原因ともなってい る。

スケールを介した抜熱を議論する場合にまず重要とな るファクターはスケールの熱伝導率／熱拡散率である。ス

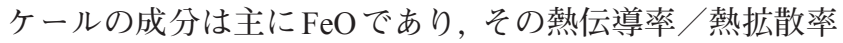
についてはいくつかの報告がある ${ }^{2-7)}$ 。測定方法, 試料の 作製方法などに違いがあるが， $700^{\circ} \mathrm{C}$ の熱伝導率の值とし ては概ね3〜 $10 \mathrm{~W} / \mathrm{mK}$ の範囲にある。一方で, 鉄の熱伝導 率については同温度で約 $28 \mathrm{~W} / \mathrm{mK}$ と報告されている ${ }^{8)}$ 。ス ケールの熱伝導率のほうが小さいことから, スケールは鋼 板冷却において熱抵抗となると考えられる。しかしなが ら, そのスケールが厚いほど, 鋼板の冷却がより早く起こ るという現象があり，これが鋼板の冷却速度の制御を困 難にしている。この現象は, 水の沸騰形態が膜沸騰から核 沸騰に遷移する温度（クエンチ点）が，スケールが厚いほ ど高くなることに起因している。このクエンチ点のスケー 儿厚さ依存性に関しても, 従来, 研究が行われている ${ }^{9-14)}$ 。

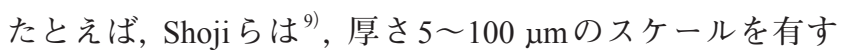
る鋼板に水スプレー冷却を行った際の鋼板内部の温度変 化を測定し, クエンチ点は, スケール厚さが $5 \mu \mathrm{m}$ の場合 に約 $300^{\circ} \mathrm{C}$ であるのに対し，100 $10 \mathrm{~m}$ の場合には約 $500^{\circ} \mathrm{C} ま$ で上昇することを見出している。Kato らは ${ }^{10)}, \mathrm{Ni}$ を 0 4.9 mass \% 含有する鋼を大気酸化させて厚さの異なるスケー

平成 29年8月2日受付＼cjkstart平成29年9月28日受理 (Received on Aug. 2, 2017 ; Accepted on Sep. 28, 2017)

1) 東京工業大学大学院理工学研究科材料工学専攻 (Department of Metallurgy and Ceramics Science, Tokyo Institute of Technology, 2-12-1 S8-7 Ookayama Meguro-ku Tokyo 152-8552)

2) 東京工業大学物質理工学院材料系 (Department of Materials Science and Engineering, Tokyo Institute of Technology)

* Corresponding author : E-mail : susa.m.aa@m.titech.ac.jp

DOI : http://dx.doi.org/10.2355/tetsutohagane.TETSU-2017-070 
ルを形成した試料を作製し，水スプレー冷却を行ってい る。スケールが厚くなるほどクエンチ点が上昇すること， またそれはスケール層の断熱効果により，鋼板表面温度が より低下することによると述べている。一方で, Fukuda ら は ${ }^{13)}$, スケールの厚さだけでなく, 表面粗さの影響にも着 目している。彼らは, SUS304の表面に $\mathrm{Al}_{2} \mathrm{O}_{3}$ の粉末を擬似 スケールとして溶射し, スケール厚さを $50 \sim 210 \mu \mathrm{m}$ の範 囲で調整している。また, 未溶射の母材表面にショットブ ラスト加工を施し, 表面粗さを3〜20 $\mu \mathrm{m} R \mathrm{a}$ の範囲で調整 している。これらの試料を用いて水スプレー冷却を行い, スケールが厚いほど, また表面粗さが粗いほどクエンチ点 が高温側に移行し，より早く核沸騰が起こることを見出し ている。以上のように, 従来の研究で, スケール厚さや粗 さのクエンチ点への影響は実験的に明らかにされていると 考えられる。

しかしながら, 従来の研究においては, 鋼材冷却時の熱 流束や熱伝達係数の導出には熱伝導逆問題解析法が適用 されており，スケール層はきわめて薄い，またその熱伝導 率が明らかになっていないという理由で, その存在を無視 した取り扱いがなされている ${ }^{13)}$ 。スケールの熱伝導率とと もに，他の必要なパラメータの值が仮定されている場合も ある ${ }^{10)}$ 。今後スケールを介した水冷却の問題をより精緻に 扱うためには，熱酸化により鋼板上に生成した $\mathrm{FeO}$ などの 熱伝導率を測定するとともに6,7,14), 水の蒸発による抜熱流 束を直接評価する方法を確立することが必須であると考え る。

水が鋼板上で沸騰する場合, 水自身の温度は概ね $100^{\circ} \mathrm{C}$ に保たれていると考えてよい。一般に水の物性值は正確 に測定されており，100 Cにおける水の標準蒸発エンタル ピーの值 $\left(\Delta H^{\mathrm{o}}{ }_{\text {water }}\right)$ も報告されている ${ }^{15)}$ 。したがって, 水 の蒸発にともなう質量変化と, 水と鋼板の接触面積が計測 できれば，水の蒸発にともなう抜熱流束の評価が可能であ る。本研究は, まずこのような原理に基づいた評価の可能 性を調査するために, 水滴の蒸発にともなう抜熱流束評価 法を開発し，本方法を用いて，スケール厚さの水のクエン チ点への影響について調査して, 本法の妥当性について検 討することを目的とする。

\section{2. 実験方法}

\section{$2 \cdot 1$ 実験装置の概略と原理}

Fig.1 に本実験装置の概略図を示す。実験装置は, 鋼試料 を加熱・酸化させるための電気炉, 電子天科, 水滴滴下装 置, 試料温度測定用の熱電対とデジタルマルチメータおよ び水滴の沸騰状態を記録するビデオカメラから構成されて いる。電子天科の上には, 試料台として耐火レンガが設置 されている。まず試料を電気炉に装入し，所定時間酸化さ せて試料表面にスケールを形成させる。その後, 耐火レン
ガ上に移動させ, 所定量の水を滴下する。滴下直後は, 試 料系は水の質量分だけ重くなるが, 蒸発が起こり, 質量は 減少していく。この質量変化を電子天科で測定する。また 試料の温度変化を熱電対で測定する。この実験結果に基づ いて, 水滴の蒸発にともなう抜熱流束 $(Q)$ を以下の式で計 算する。

$$
Q=\Delta H^{\mathrm{o}}{ }_{\text {water }} \times\left(\Delta m \Delta t^{-1}\right) / S
$$

ここで, $\Delta H_{\text {water }}^{\mathrm{o}}=2257 \mathrm{~J} / \mathrm{g}$ である ${ }^{15)}$ 。また,$\Delta m \Delta t^{-1}$ は水滴 の蒸発速度であり, 水の質量変化の結果より求める。 $S$ は水 と鋼板の見かけの接触面積であり, ビデオカメラによって 記録された画像から推定する。なお，今回は実施していな いが, 天科上の試料台に水の容器も設置すると, 断続的に 水を滴下して冷却する実験にも対応できる可能性がある。

\section{$2 \cdot 2$ 試料}

試料として極低炭素鋼板 $\left(40 \times 40 \times 5 \mathrm{~mm}^{3}\right)$ を用いた。 その化学組成を Table 1 に示す。水滴の試料からの落下を防 ぐために, Fig. 2 に示すように，試料中央部に $\phi 30 \mathrm{~mm}$, 深さ $3 \mathrm{~mm}$ の円形の凹みを作製した。凹部底面は精密研磨を施 し，表面粗さを統一した。また，熱電対を設置するために， 底面に孔 $(\phi 1.5 \mathrm{~mm}$, 深さ $1.5 \mathrm{~mm})$ を開けた。実験に用いる 前に, 機械油を除去するために, エタノールで超音波洗浄 を行った。

\section{$2 \cdot 3$ 実験手順}

まずFig.1に示した電気炉で試料の酸化を行った。高温 では, 試料表面に形成する酸化鉄が炉中のセラミックス製 試料台と反応し, 接着してしまう可能性がある。これを防 ぐために, 試料はSUS310S板 (厚さ $0.2 \mathrm{~mm}$ ) の上に設置し

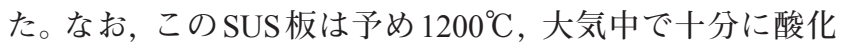
し，その表面にクロミア皮膜を形成させたものを用いた。

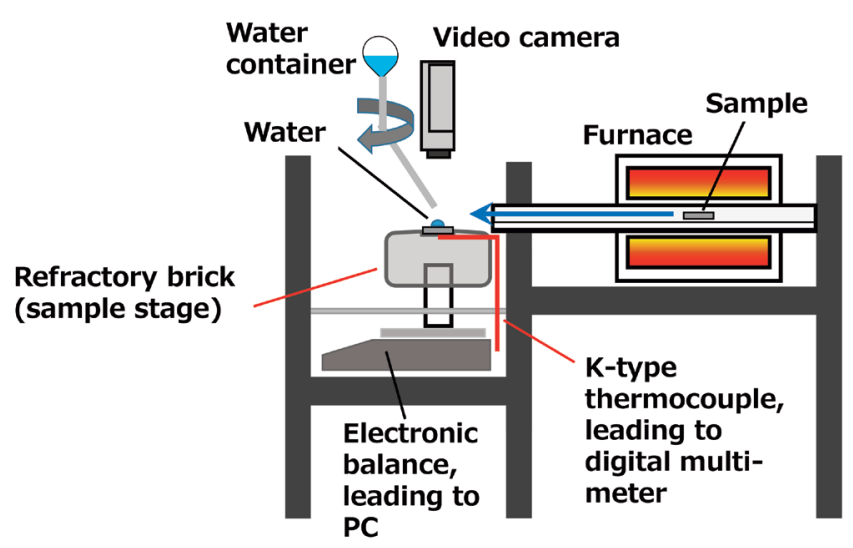

Fig. 1. Schematic diagram of experimental apparatus. (Online version in color.)

Table 1 Chemical compositions of samples. (mass\%)

\begin{tabular}{ccccccc}
\hline Components & Fe & C & Si & Mn & P & S \\
\hline Mass $\%$ & Bal. & 0.001 & 0.01 & 0.14 & 0.019 & 0.007 \\
\hline
\end{tabular}


試料の酸化温度は $850^{\circ} \mathrm{C}$ とた。この温度は鉄の $\alpha \rightarrow \gamma$ 変態 温度よりも $50^{\circ} \mathrm{C}$ 以上低いために, 鉄の相変態にともなう体 積変化によるスケールの剥離は起こらなかった。また, 試 料の酸化時間を 10，15，20，30 min と変化させて，それぞ れ厚さ $40,58,77,103 \mu \mathrm{m}$ のスケールを形成させた。この 厚さは $3 \cdot 1$ で述べる観察結果によるものである。

スケールを形成させた後, 石英棒を用いて高温の試料 を電子天科上の試料台に移動させるとともに, 試料にK 型 熱電対を設置した。 $\mathrm{K}$ 型熱電対は $\phi 1 \mathrm{~mm}$ のステンレスシー ス型のものであり, その先端部約 $3 \mathrm{~mm} 90^{\circ}$ 曲げ加工し, Fig.1に示すように, 横方向から試料底面に開けた測温用の 孔にとり付けた。ついで, 試料凹部の表面温度が $600^{\circ} \mathrm{C}$ と なったときに, 水滴約 $3 \mathrm{~g}$ を叫部に滴下した。試料を取り出 してから表面温度が $600^{\circ} \mathrm{C}$ となる時間は, 予備実験で試料 表面に溶接した熱電対を用いて $46 \mathrm{~s}$ と決定した。なお, $3 \mathrm{~g}$ の水は凹部全体を覆うことができるが, 試料から零れ落ち ない程度の量であった。

その後, 水の蒸発にともなう質量変化, 試料内部の温度 変化および水滴が沸騰する様子をそれぞれ電子天科, 熱電 対打よびビデオカメラを用いて記録した。水滴の質量は電

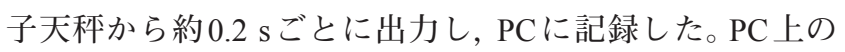
表計算ソフトには，それぞれの質量を測定した時間を 0.001 $\mathrm{s}$ 単位まで記録した。ビデオカメラは試料直上に設置した。 なお, 水の沸騰が激しい場合, その蒸気でビデオカメラの レンズが曇ってしまうため, カメラは試料から $50 \mathrm{~cm}$ 以上 離して設置した。

\section{$2 \cdot 4$ 試料の分析}

実験後の各試料について, 試料凹部の表面粗さをレー ザー顕微鏡で測定した。 5 視野 ( 1 視野の走查範囲 : 256.0

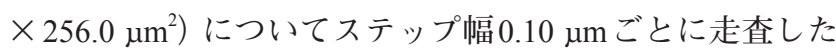
のち, 各視野から任意の3本を選び, 断面曲線を得た。こ れら合計 15 本の断面曲線から算術平均粗さ $R \mathrm{a}$, 二乗平均

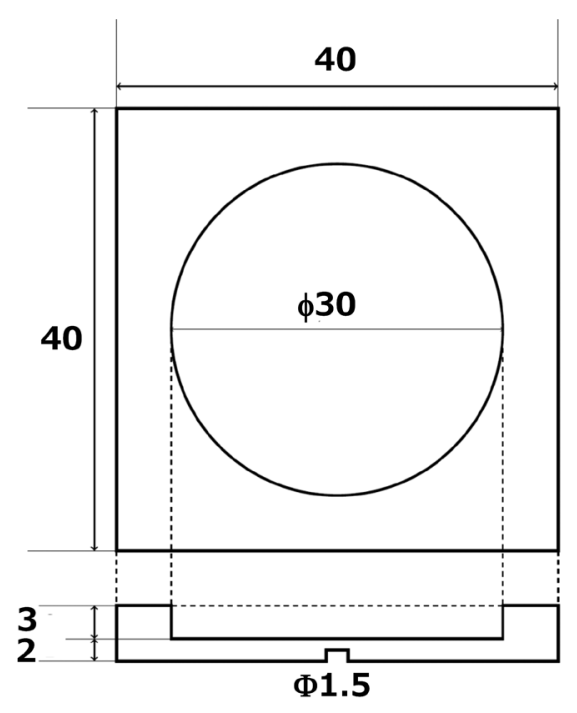

Fig. 2. Dimensions of sample (in $\mathrm{mm}$ ).
平方根粗さ $R \mathrm{q}$, 最大高さ粗さ $R \mathrm{z}$ （最低部と最高部の高さの 差)の3 種類を表面粗さのパラメータとして算出した ${ }^{16)}$ 。

スケールの相同定にはXRDを用いた。測定は試料の凹 部に対して行った。X線源としてはCoを用い, 走査角度 範囲は $20 \sim 80^{\circ}$ で, サンプリング幅は $0.02^{\circ}$ 毎, 測定速度は $1^{\circ} \mathrm{s}^{-1}$ とした。

さらに測定後の試料断面をSEMで観察するために, 試 料を樹脂埋め・切断した。この切断による影響を避けるた め, 切断面を $1 \mathrm{~mm}$ 以上研磨し, 鏡面に仕上げた。試料は研 磨後洗浄し，十分に真空引きしたのち，表面に金コーティ ングを施し, FE-SEM/EDS 観察に供した。撮影した画像の スケール／鋼板界面とスケール／樹脂界面に直線を引き， その間の距離を画像解析ソフトで算出することによって, 酸化スケールの厚さを決定した。また, BSE像のコントラ ストの違いから層構造を観察し，加えて EDSで組成分析を することでスケール各層の構成相の推定を行った。最終的 にはXRDおよびFE-SEM/EDSの結果を用い, 各実験条件 に打いて試料表面に形成したスケールの構成相および層構 造の決定を行った。

\section{$2 \cdot 5$ 鋼板 $/$ 水滴の接触面積の推定}

ビデオカメラによって記録した動画から静止画を 1 $5 \mathrm{~s}$ ごとに切り出し, 画像解析ソフトを用いて水滴および試料 凹部の各領域のピクセル数 $\left(p_{\text {water }}\right.$ およ゙゙ $\left.p_{\text {concave }}\right)$ を求めた。 これらの值を用いて, 接触面積 $(S)$ を式 (2) から求めた。

$$
S=\pi \times\left(d_{\text {concave }} / 2\right)^{2} \times p_{\text {water }} / p_{\text {concave }}
$$

ここで, $d_{\text {concave }}$ は四部の内径であり,$\pi$ は円周率である。1〜 $5 \mathrm{~s}$ ごとに決めた接触面積を任意の関数で近似し, 接触面積 の時間変化を得た。

\section{3. 実験結果}

\section{$3 \cdot 1$ 試料の特徵 \\ 表面粗さ}

Fig.3に, 酸化前の試料打よび厚さの異なるスケールを 有する 4 試料の表面粗さパラメータ $R \mathrm{a}, R \mathrm{q}$ およびRZをス ケール厚さに対して示す。酸化の前後で表面粗さが変化し ているものの, スケールの厚さによる差は見られず, いず れも $R \mathrm{a}=3 \mu \mathrm{m}, R_{\mathrm{q}}=3.5 \mu \mathrm{m}, R_{\mathrm{Z}}=24 \mu \mathrm{m}$ 程度である。ス ケール厚さ $58 \mu \mathrm{m}$ 打よび $77 \mu \mathrm{m}$ の試料で $R \mathrm{z}$ の值が少し大き いように見えるが，ばらつきを考虑すると，4者は一致し ているといえる。これより，スケールの厚さによって表面 粗さが変化することはなく, スケールの厚さのみを変化さ せた試料を作製していたといえる。なお，レーザー顕微鏡 での観察の結果, 酸化前の試料表面には, 機械加工による 周期的な表面の起伏が観察された。このため, 本研究の測 定では, 加工痕に対して常に垂直に粗さ測定のための断面 曲線を取った。しかしながら, 酸化後の試料では, 結晶粒 
は観察されたものの，機械加工の跡は認められなかった。 したがって，スケールには，酸化前の表面性状の影響はな いといえる。

\section{XRD によるスケールの相同定}

Fig.4にスケール厚さ $40 \mu \mathrm{m}$ の試料で測定したXRD プロ ファイルを示す。このプロファイルには, $\mathrm{FeO}$ および $\mathrm{Fe}_{3} \mathrm{O}_{4}$ のピークが認められる。他の試料についても測定を行った ところ，全ての試料で $\mathrm{FeO}$ 打よび $\mathrm{Fe}_{3} \mathrm{O}_{4}$ のピークが測定さ れた。よって, 本実験条件で形成したスケールは $\mathrm{FeO}$ およ び $\mathrm{Fe}_{3} \mathrm{O}_{4}$ の2相から構成されていると判断できる。

\section{FE-SEM/EDSによる断面観察および組成分析}

Fig.5にスケール厚さ103 $\mu \mathrm{m}$ の試料のBE像を示す。ス ケールは2層構造となっていることがわかる。BSE像は, 原子量の小さい元素が多く含まれる領域ほど暗く映る。す なわち，このスケールは，表層に近い側が酸素の濃度の高 い酸化物から形成されている。XRDの結果を考慮すると， 本スケールは表面から順に $\mathrm{Fe}_{3} \mathrm{O}_{4}, \mathrm{FeO}$ であるといえる。同 様の結果は他のスケールについても観察された。この結果 は，既往の研究報告と一致している ${ }^{17,18)}$ 。また, Fig.5のス ケール内部には多くのボイドが観察される。これらのボイ ドは，厚さ方向に並んでおり， $\mathrm{FeO} の$ 結晶粒に沿って生成

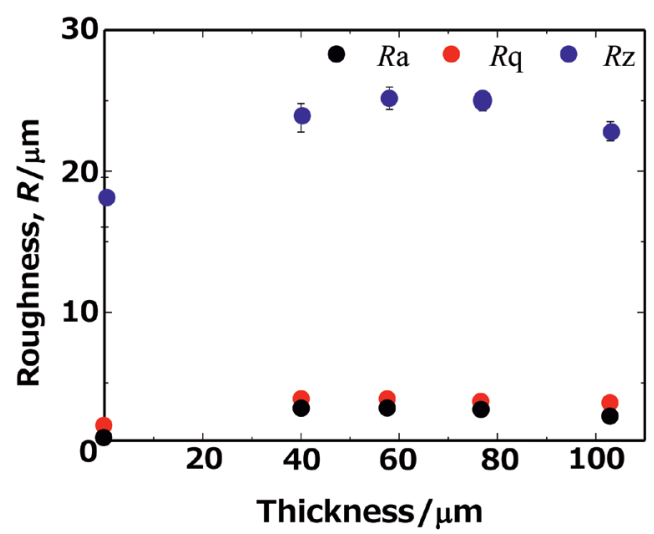

Fig. 3. Relation between surface roughness parameters and oxide scale thickness. (Online version in color.)

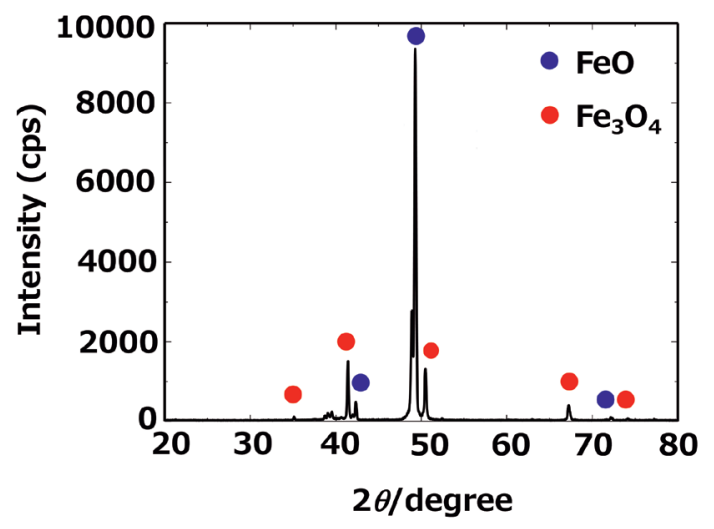

Fig. 4. XRD profile of sample with oxide scale $40 \mu \mathrm{m}$ thick (Target: Co). (Online version in color.)
したと考えられる。ボイドは, 鋼板の近くのほうが大きい 傾向にある。さらに，スケール／鋼板界面には，大きさが 1 $\mu \mathrm{m}$ 以下のボイドや不純物の濃化層が確認できる。後者は, 試料に用いた極低炭素鋼に含まれている Fe以外の不純物 元素が濃化してできた層であり，スケール内部よりも多く のボイドを含んでいる。同様のことが他のスケール試料に ついても確認できた。

\section{$3 \cdot 2$ ビデオカメラで記録した水沸騰の様子}

Fig.6 (a)〜 (e) は，スケール厚さ40 $\mu \mathrm{m}$ の試料において 沸騰の様子を記録した動画から時系列で5枚を取り出した ものである。水滴は, Fig.6 (a) に示すように，滴下直後は 試料凹部全体を覆っていたが，(b) のように，激しく踊る ような不安定な沸騰を示しながら蒸発し，(c) のように， 一滴の水滴となり, 安定な膜沸騰状態となった。その後も, 水は複数の水滴に分解することはなく, 一滴のままで膜沸 騰を維持しながら，(d) のように, 小さな水滴に変化し, 最 終的に核沸騰を起こし，その直後に（e）のように，ほとん

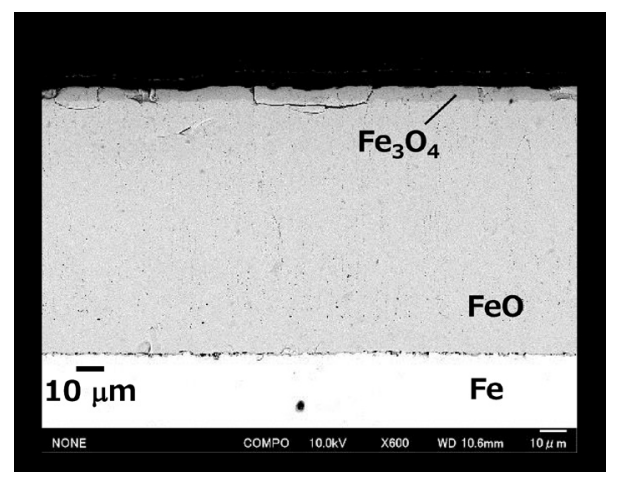

Fig. 5. BE image of cross section of sample with oxide scale $103 \mu \mathrm{m}$ thick.

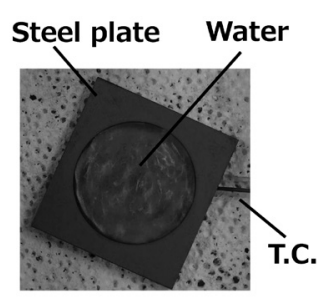

(a)

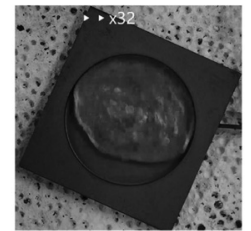

(b)

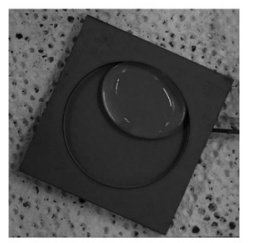

(c)

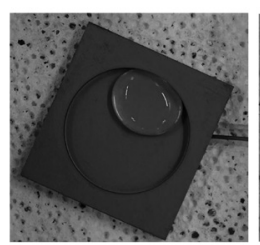

(d)

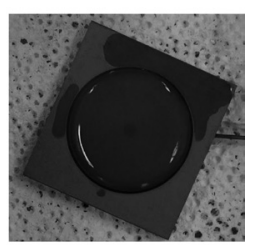

(e)
Fig. 6. Boiling behavior of water observed in experiment for oxide sample with scale $40 \mu \mathrm{m}$ thick; (a) just after water was dropped, (b) before film boiling was stable, (c) after film boiling was stable, (d) just before nucleate boiling happened, and (e) just after nucleate boiling happened. 
ど全て蒸発した。このような沸騰形態の変化は, 他の試料 においても同様に観察された。

これらの画像をもとに試料／水滴の接触面積を推定し た。その推定結果を Fig.7に示す。なお，今回の実験では， クエンチの瞬間に水が一気に蒸発するとともに湯気も発生 したため, 水滴の画像が取得できず，接触面積の推定がで きなかった。そのため, 接触面積の值としてはクエンチ直 前までの結果を示している。滴下直後の接触面積は，いず れの試料についても，上下に振動しているように見える。 ここでの状態は, 膜沸騰ではあるが, 試料叫部全域を水滴 が覆っているために，蒸気の離脱が行われにくく，そのた めに上下に振動していると考えられる。約 $50 \mathrm{~s}$ 以降は，い ずれの試料でも接触面積はほぼ同じであり，緩やかに減少 している。ここでは，接触面積が試料凹部の面積より小さ くなっており, 蒸気の離脱が液滴周辺から行われるため に, 膜沸騰が安定したと推定される。今回の実験では, 膜 沸騰中の水と試料の接触面積は，スケール厚さの影響を受 けていないといえる。また，接触面積の減少速度は徐々に 小さくなっていく様子がわかる。これは試料の冷却にとも ない, 試料から水へ伝達される熱量が小さくなっているこ とに対応すると考えられる。

\section{$3 \cdot 3$ 質量および温度変化}

Fig. 8 および9に, 電子天科で測定した試料上の水滴の質 量および $\mathrm{K}$ 型熱電対で測定した試料内部温度の経時変化を 示す。横軸は水を滴下して冷却を開始してからの時間であ る。スケール厚さ $40 \mu \mathrm{m}$ の試料のデータを例に取り説明す ると, 水滴の滴下 $(t=0 \mathrm{~s})$ と同時に質量は約 $2.7 \mathrm{~g}$ 増加し, 温度は約 $70^{\circ} \mathrm{C}$ 急激に減少している（Fig.6 (a) に対応）。不 安定な沸騰（Fig.6（b）に対応）を経た後，t〜40 sにおいて 質量変化の速度が変化し，その後滑らかな減少を示してい る。ここで不安定な沸騰から安定な膜沸騰に移行したと考 えられる (Fig.6 (c) に対応)。さらに $t$ 〜270 s までは膜沸 騰が続き，質量，試料温度ともに緩やかに減少している。 膜沸騰中に水滴が部の中を移動し, 熱電対直上の位置か

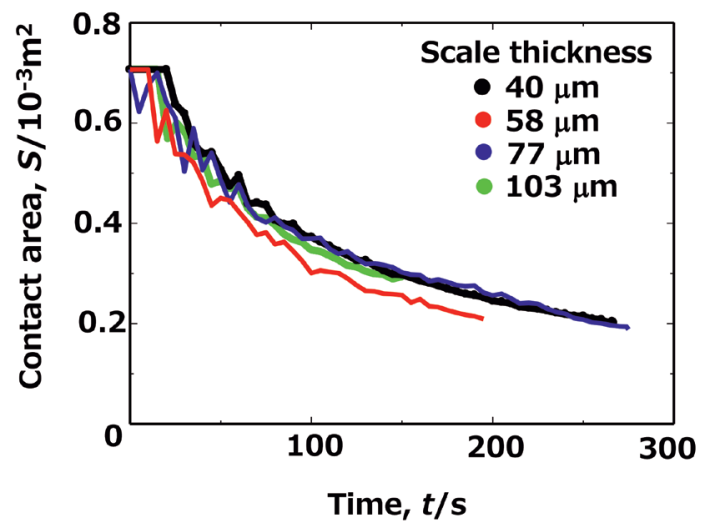

Fig. 7. Contact area between sample and water as function of time, taken from video images. (Online version in color.)
らずれることがあったが，それによる温度の急激な変化は 観測されなかった（Fig.6 (c)〜 (d) に対応)。t〜270 s におい ては，質量および試料温度はともに急激に減少している。 この時点で, 水滴は急激に蒸発し, 試料上の水はほぼ全て 蒸発した (Fig.6 (e) に対応)。本研究では，この時点で膜沸 騰から核沸騰への遷移が起こったと判断し，このときの試 料内部温度をクエンチ点として求めた。スケール厚さが異 なる他の試料においても，同様の変化が観測され，スケー ル厚さ 40, 58, 77, $103 \mu \mathrm{m}$ の各試料のクエンチ点を, Fig.9 より，それぞれ $131 ， 167,121,182^{\circ} \mathrm{C}$ と求めた。スケール厚 さが40, 58, $103 \mu \mathrm{m}$ のつを比較した場合には，スケール が厚いほどクエンチ点が上昇しているが，全てを比較した 場合には，そのように断定することは難しい。

\section{4. 考察}

\section{4 ・1 テイラー不安定性と膜沸騰状態における水滴の安定性}

Fig.8に示したように，水の質量変化はいずれのスケール 厚さの試料の実験でも，水滴下後 $40 \sim 50 \mathrm{~s}$ において滑らか

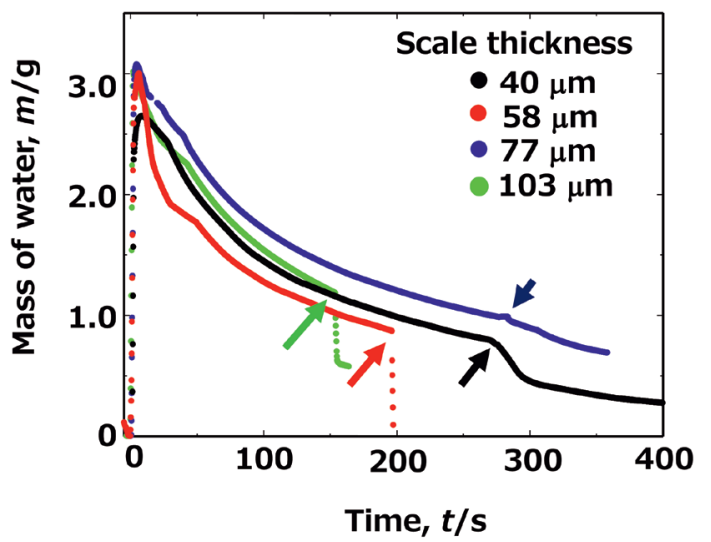

Fig. 8. Mass change with time of water droplet: the arrows represent the respective quench points. (Online version in color.)

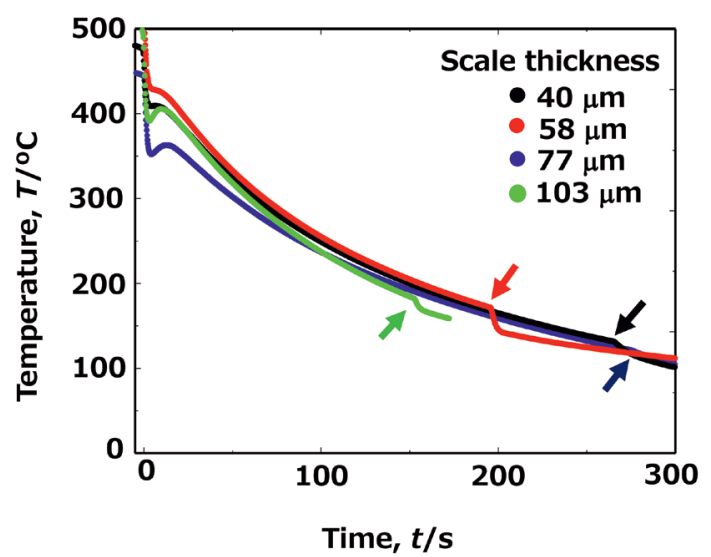

Fig. 9. Temperature change with time at sample inside: the arrows represent the respective quench points. (Online version in color.) 
な減少へと移行し，この時点で安定した膜沸騰を示した。 ビデオカメラによる画像を見ると，滴下直後は約 $30 \mathrm{~mm}$ で あった水滴の直径は, 膜沸騰に移行するときにはいずれも $15 \mathrm{~mm}$ 程度となっていた。ここでは，この現象をテイラー 不安定性の観点から考察する ${ }^{19)}$ 。膜沸騰とは, 水滴よりも 密度の小さい蒸気膜が水滴の下に潜り込んだ状態であり, そのような状態に打いては，水滴が安定して存在できる臨 界直径が存在する。その臨界直径 $d_{\text {limit }}$ は式 (3) で計算する ことができる。

$$
d_{\text {limit }}=2 \pi\left(\frac{\sigma}{g\left(\rho_{\mathrm{L}}-\rho_{G}\right)}\right)^{\frac{1}{2}}
$$

ここで, $g$ は重力加速度, $\sigma$ は $100^{\circ} \mathrm{C}$ における液体の水の表 面張力, $\rho$ は $100^{\circ} \mathrm{C}$ における密度であり，添え字 $\mathrm{L}$ と $\mathrm{G}$ はそ れぞれ液体の水と水蒸気を表している。 $\sigma=58.84 \times 10^{-3}$ $\mathrm{Jm}^{-2}, g=9.8 \mathrm{~ms}^{-2}, \rho_{\mathrm{L}}=0.9583 \times 10^{3} \mathrm{kgm}^{-3}, \rho_{\mathrm{G}}=0.598$ $\mathrm{kgm}^{-3}$ を式 (3) に代入すると ${ }^{20)}, d_{\text {limit }}=15.7 \mathrm{~mm}$ が得られ た。すなわち, 鋼板上の水滴直径が $15.7 \mathrm{~mm}$ 以下になると, 膜沸騰中の水滴は安定することになる。この結果はビデオ カメラでの観察結果とよく一致している。

\section{$4 \cdot 2$ 蒸発速度, 接触面積および試料温度の近似}

ここから先の考察では, Fig.7〜9で示した水滴の質量変 化，接触面積変化および試料温度変化のデータを用いる が，これらのデータには，ノイズが大きい部分がある。ま た，これらのデータはそれぞれ独立の装置で測定されてい るために，滴下からの時間 $t$ にわずかなずれが生じている。 そこで，電子天科で得られた質量に対応する時間に他の結 果の時間を合わせた上で，蒸発速度，接触面積および試料 温度を以下のように近似した。

具体例としてスケール厚さ $77 \mu \mathrm{m}$ の試料の結果を取り上 げて近似の方法を説明するが，他の試料のデータについて も同様の手順で近似を行っている。まず，Fig.8の水滴の質 量変化から算出した蒸発速度 $\Delta m \Delta t^{-1}$ を Fig.10に黒色のプ ロットで示す。その結果は非常にノイズが大きい。これは，

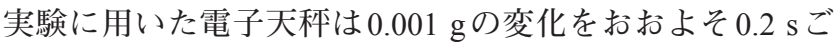
とに測定しているために, $0.005 \mathrm{gs}^{-1}$ 以下の蒸発速度の変 化は検知できないことによる。このため, Fig.8の水滴の質 量変化を時間の関数 $m(t)$ に最小二乗法により近似して, その近似式を時間で微分することで蒸発速度を得ることと した。 $t<50 \mathrm{~s}$ の時間域では，5点ずつ移動平均をとって近 似した。 $t>50 \mathrm{~s}$ の領域では膜沸騰が安定した部分につい て対数近似を用いたところ，式 (4) が得られ，その $R^{2}$ 值は 0.999 であった。

$$
m(t)=5.1788-7.5001 \ln (t)
$$

また式 (4) を $t$ で微分すると, 蒸発速度は式 (5) のように 得られる。 $d m / d t=-7.5001 / t$

Fig.10にはこのような近似によって得られた蒸発速度も赤 色のプロットで示している。

つぎにFig.7に示した接触面積についても近似を行った。 水が蒸発して接触面積が減少し始めた $t=15 \mathrm{~s}$ 以降の值に ついては，以下のような近似式が得られた。

$$
S(t)=1.6194-2.3823 \ln (t)
$$

この $R^{2}$ 值は 0.996 であった。この近似式による接触面積 と初めに求めた実験值の比較を Fig.11に示す。

試料内部温度に関しては, 測定間隔が $0.1 \mathrm{~s}$ と短かったた め, 近い時間の值を引用し, 不足するところは線形近似す ることで補完した。補完前後の試料内部温度を Fig. 12 に示 す。この場合は，補完前後でほとんど差は見られない。

\section{$4 \cdot 3$ 水滴の蒸発による鋼板試料からの抜熱流束}

Fig.13に，近似した蒸発速度および接触面積を用いて， 式 (1) から算出した鋼板からの抜熱流束 $Q$ の計算結果を

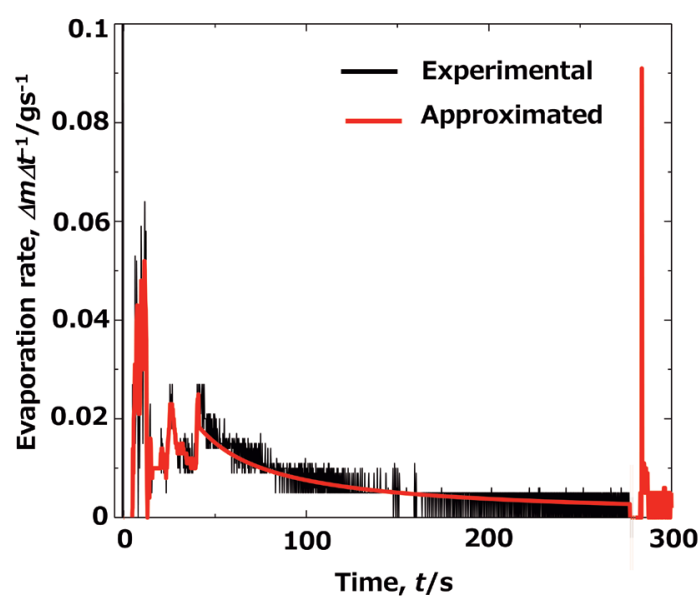

Fig. 10. Comparison between experimental and approximated evaporation rates of water for sample with oxide scale $77 \mu \mathrm{m}$ thick. (Online version in color.)

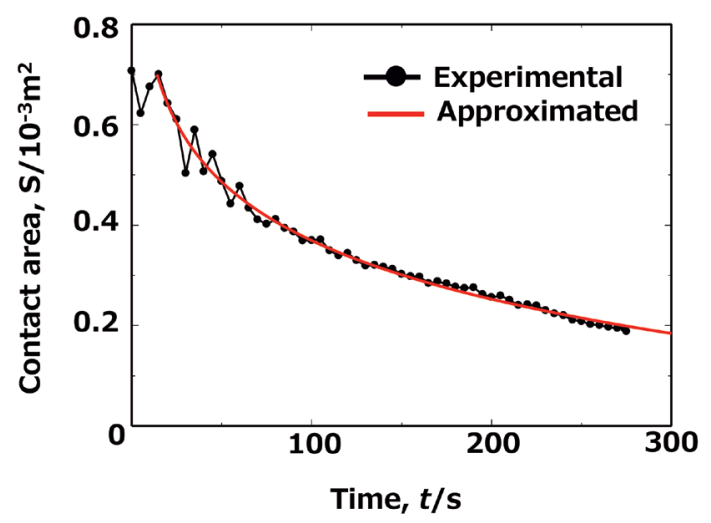

Fig. 11. Comparison between experimental and approximated contact areas between sample and water for sample with oxide scale $77 \mu \mathrm{m}$ thick. (Online version in color.) 
時間に対して示す。なお，今回の実験では，Fig.8に示した ように, クエンチ点での水の質量変化は測定できたが，先 に述べたように，接触面積の推定ができなかった。その ため，熱流束の值としてはクエンチ直前までの結果を示 している。滴下直後から約 $50 \mathrm{~s}$ の領域では, 抜熱流束の值 は，ばらつきは大きいものの，比較的大きな值（100～200 $\left.\mathrm{kWm}^{-2}\right)$ を取っている。この領域では，水が激しく踊るよ うな不安定な沸騰を示したため蒸気膜が安定せず，ばらつ きが大きくなったものと考えられる。また，不安定な激し い沸騰から安定な膜沸騰に至るまでの遷移域にあったた め，抜熱流束が大きな值となったと考えられる。約 $50 \mathrm{~s}$ 以 降では，沸騰形態が安定した膜沸騰状態へと移行し，抜熱 流束は緩やかに減少している。抜熱流束の值は，いずれの スケール厚さの試料でも $30 \sim 50 \mathrm{kWm}^{-2}$ で概ね横ばいとな り，その後，クエンチに至り蒸気膜が崩壊する。クエンチ の直前の熱流束の值は，スケール厚さ 40, 58, 77, $103 \mu \mathrm{m}$ の試料に打いて，それぞれ $31 ， 35,33,43 \mathrm{kWm}^{-2}$ となり， 大きな差はなく，またスケール厚さに対して系統的な傾向 も見られない。

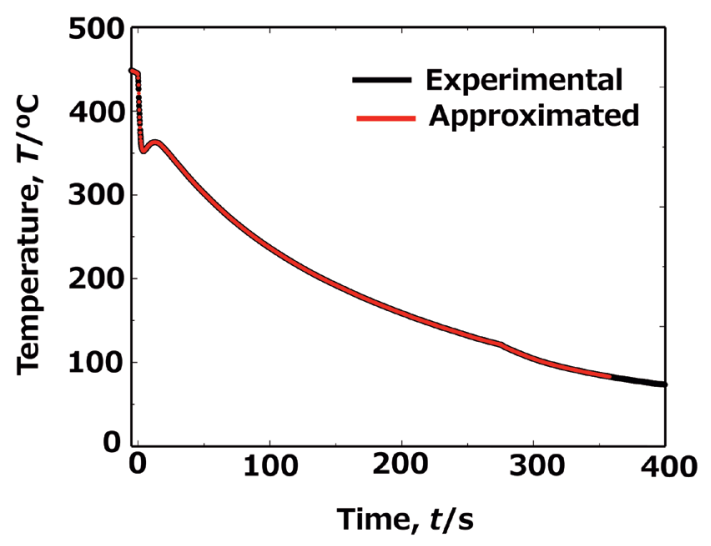

Fig. 12. Comparison between experimental and approximated temperatures at sample inside for sample with oxide scale $77 \mu \mathrm{m}$ thick. (Online version in color.)

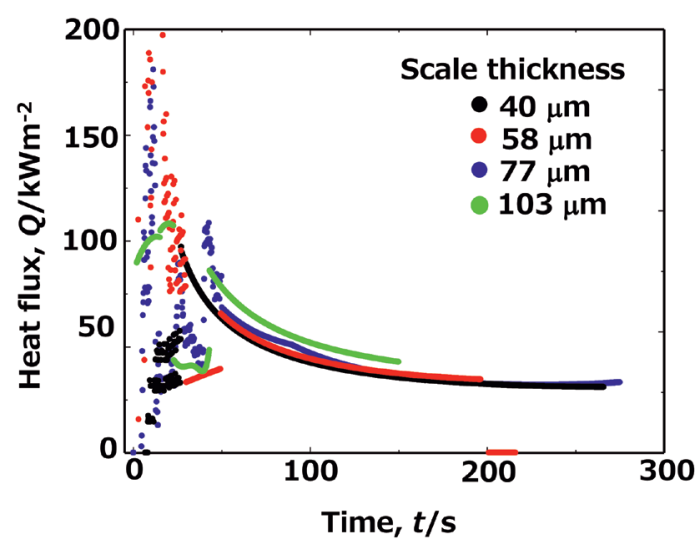

Fig. 13. Heat flux extracted from steel surface by evaporation of water. (Online version in color.)

\section{$4 \cdot 4$ 蒸気膜厚の推定}

Fig.14に本実験系のモデルを示す。同図には, 鋼板試料 から水滴に至る領域に打ける温度分布も描いている。この 系が擬定常状態にあると仮定すると, 抜熱流束 $Q$ はフーリ エの法則を用いて式 (7) により表せる ${ }^{21)} 。$

$$
Q=\frac{T_{\text {steel }}-T_{\text {water }}}{d_{\text {steel }} / k_{\text {steel }}+d_{\text {scale }} / k_{\text {scale }}+d_{\text {film }} / k_{\text {film }}}
$$

ここで， $T, d, k$ は，それぞれ，添え字で示された部分の温 度，厚さおよび熱伝導率である。なお，各界面における熱 抵抗は無視している。式 (7) を $d_{\text {film }}$ について解くと, 式 (8) が得られる。

$$
d_{\text {film }}=\left(\frac{T_{\text {steel }}-T_{\text {water }}}{Q}-\left(d_{\text {steel }} / k_{\text {steel }}+d_{\text {scale }} / k_{\text {scale }}\right)\right) \times k_{\text {film }}
$$

ここでは, 式 (8) を用いて蒸気膜厚の推定を行う。その結 果を Fig.15に蒸気膜厚の経時変化として示す。この推定に 扎いては， $T_{\text {steel }}$ には実験值を用い，また， $T_{\text {water }}$ は $100^{\circ} \mathrm{C} と$ 仮 定している。実験中の水滴にK型熱電対を挿入したとこ

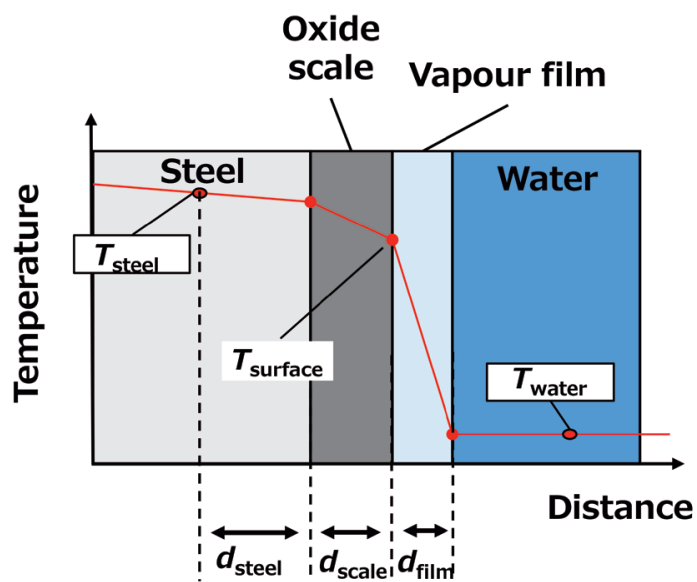

Fig. 14. A model of present experimental system with temperature distribution. (Online version in color.)

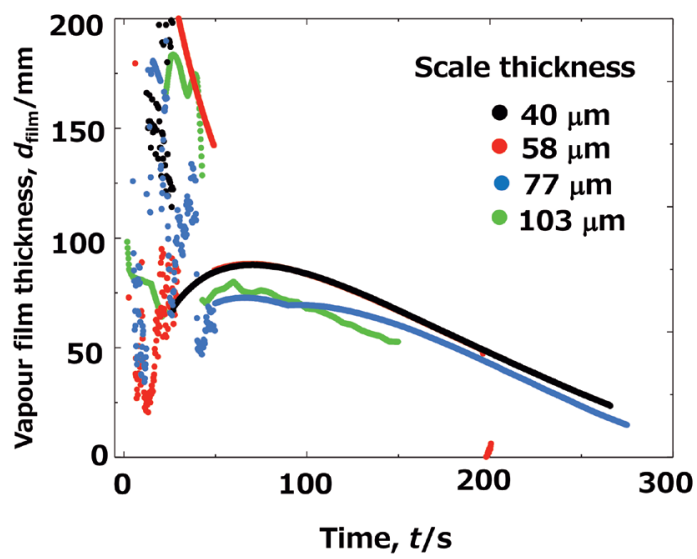

Fig. 15. Vapour film thickness as function of time. (Online version in color.) 
ろ，約 $98^{\circ} \mathrm{C}$ の温度が記録されたが，水滴が浮揚している

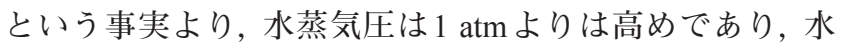
滴の下面は $100^{\circ} \mathrm{C}$ 以上になっていると考えられるためであ る。 $k_{\text {scale }}, k_{\text {steel }}$ および $k_{\text {film }}$ には，それぞれ， $6.5 \mathrm{Wm}^{-1} \mathrm{~K}^{-122)}$ ， $45 \mathrm{Wm}^{-1} \mathrm{~K}^{-123)}$ ，および $0.0259 \mathrm{Wm}^{-1} \mathrm{~K}^{-1}$ の值を用いてい る ${ }^{15)}$ 。なお， $k_{\text {steel }}$ については，キルド鋼の值を参考に仮定 した。最後に, $d_{\text {steel }}$ の值は, 鋼板厚 $2 \mathrm{~mm}$ から熱電対用の孔 の深さとスケール厚さを差し引いた值としている。Fig.15

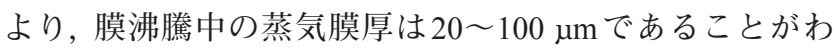
かる。滴下直後から約 $50 \mathrm{~s}$ の領域の蒸気膜厚には意味はな いが，膜沸騰中の蒸気膜厚は鋼板の冷却にともなって徐々 に薄くなっていることがわかる。クエンチ直前における蒸 気膜厚は，いずれのスケール厚さの試料でも $45 \mu \mathrm{m}$ 以下で あった。なお，クエンチ直前における蒸気膜厚にも，スケー ル厚さと間に明瞭な相関関係は見られていない。ただし， 20〜100 $\mu \mathrm{m}$ という膜厚の值は, 膜沸騰中の水滴を水平方向 から観察した報告から読み取れる蒸気膜厚と同じオーダー である ${ }^{24,25)}$ 。このことから，本装置による抜熱流束の測定 やここで行った蒸気膜厚の推定には合理性はあると判断 できる。より精緻な考察を行うためには, より正確な熱伝 導率の值とその温度依存性, 界面熱抵抗を与える必要があ る。

\section{$4 \cdot 5$ 本実験系の律速段階}

Fig.14に示した本実験系のモデルにおいて，鋼板からス ケール表面までの領域における熱伝導を考える。この領域 にフーリエの法則を適用すると, 式 (7) は式 (9) のように なる。

$$
Q=\frac{T_{\text {steel }}-T_{\text {surface }}}{d_{\text {steel }} / k_{\text {steel }}+d_{\text {scale }} / k_{\text {scale }}}
$$

ここで $T_{\text {surface }}$ はスケール表面の温度である。 $T_{\text {steel }}-T_{\text {surface }}=$ $\Delta T$ と定義して, 式 (9) を $\Delta T$ について解くと,

$$
\Delta T=Q \times\left(d_{\text {steel }} / k_{\text {steel }}+d_{\text {scale }} / k_{\text {scale }}\right)
$$

式中の $\left(d_{\text {steel }} / k_{\text {steel }}+d_{\text {scale }} / k_{\text {scale }}\right)$ 項は定数であるとしているの で， $\Delta T$ は抜熱流束 $Q$ によって変化する。Fig.13に示したス ケール厚さ $40 \mu \mathrm{m}$ の試料の結果を用いて計算した $\Delta T$ の值 をFig.16に示す。これより， $\Delta T$ は全範囲において $2^{\circ} \mathrm{C}$ 以下 であることがわかる。一方Fig.9からは, 鋼板と水の間には 約 $300^{\circ} \mathrm{C}$ か $20^{\circ} \mathrm{C}$ 温度差があることが分かる。これらの ことより, 厚さ数 $10 \mu \mathrm{m}$ の蒸気膜の中に大きな温度勾配が 存在し，この部分の熱伝導が律速段階であるということが 本熱流束測定からも襄付けられたといえる。すなわち，ス ケールは鋼板の冷却において熱抵抗として作用するが，本 測定条件における膜沸騰においては，その効果は小さく， そのために，スケール厚さのクエンチ点への影響が捉えら れなかったと考えられる。

水スプレー冷却など現実の水冷却プロセスでは, 運動量
をもった水が断続あるいは連続的に鋼板表面に供給され る。その運動量によって, 水蒸気膜厚が本実験の推定值よ りも小さくなる。そのような場合には，律速段階がスケー ル中に移る，あるいは混合律速となり，スケール厚さがク エンチ点に影響する可能性がある。2・1で述べたように， 本実験系において電子天科上に水の滴下装置も設置して, 断続的に水を滴下して冷却する実験を行うと新たな知見が 得られる可能性があると考えられる。

\section{5. 結言}

$100^{\circ} \mathrm{C}$ における水の標準蒸発エンタルピーの值を利用し て, 鋼板上の一滴の水滴の蒸発にともなう抜熱流束を評価 する装置を開発し，その方法を用いて，極低炭素鋼の表面 に形成した $\mathrm{FeO}$ を主体とするスケール厚さのクエンチ点へ の影響について調査した。

・ビデオで撮影された膜沸騰および核沸騰の様子と水の質 量および鋼板の温度変化はよく対応していた。スケール 厚さ 40, 58, 77, $103 \mu \mathrm{m}$ の各試料のクエンチ点はそれぞ れ $131,167,121,182^{\circ} \mathrm{C}$ であった。また，クエンチ直前で の抜熱流束の值は，それぞれ31，35, 33, $43 \mathrm{kWm}^{-2}$ と推 定できた。しかしながら，いずれについても，スケール 厚さとの相関関係は見られなかった。

・膜沸騰時に本実験系が擬定常状態にあったと仮定し, フーリエの法則を適用して繁気膜厚を推定したところ, 鋼板の冷却にともなって約 $100 \mu \mathrm{m}$ から約 $20 \mu \mathrm{m}$ まで薄 くなることがわかった。この膜厚の值は, 実験的に蒸気 膜の存在を観察した報告から推定される值と同じオー ダーであるため, 本装置による抜熱流束の評価や蒸気膜 厚の推定には合理性はあると結論できる。

・本実験系の律速段階について考察したところ, たとえば 厚さ $40 \mu \mathrm{m}$ のスケール内には $2^{\circ} \mathrm{C}$ 以下の温度差しかない のに対し, 鋼板と水の間には約 300 から $20^{\circ} \mathrm{C}$ の温度差が あると推定された。すなわち, 蒸気膜中の熱伝導が全体 の熱伝達を支配している可能性があり, そのために，ス

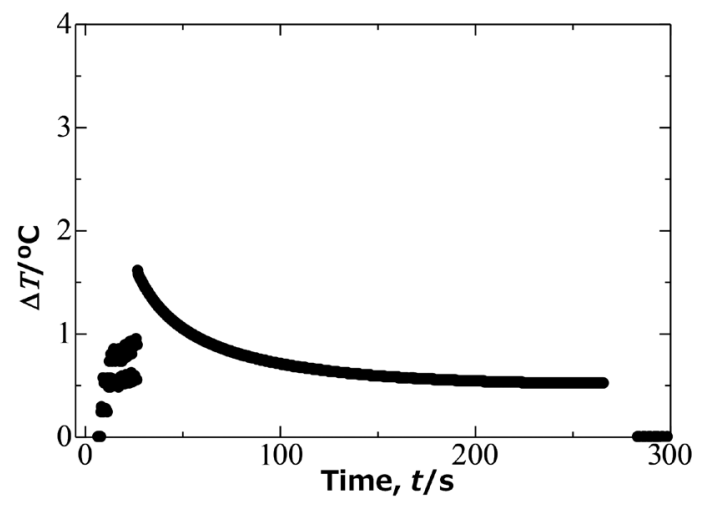

Fig. 16. Difference between $T_{\text {steel }}$ and $T_{\text {surface }}(\Delta T)$ as function of time, for sample with oxide scale $40 \mu \mathrm{m}$ thick. 
ケール厚さのクエンチ直前での抜熱流束への影響が捉え られなかったと考えられる。

\section{謝辞}

本研究は，2014～2017年に一般社団法人 日本鉄鋼協会· 圧延理論部会に設置された研究会 II「スケールの伝熱特性 支配因子調查」のプロジェクトの1つとして実施されたも のである。日本鉄鋼協会からの研究費の支援ならびに研究 会委員の皆様からの有益なご助言に感謝の意を表します。 また, 修士課程学生の六岡諒介氏には一部の図面の準備に 協力をいただきました。

\section{文献}

1 ) I.S.Park: ISIJ Int., 53(2013), 71.

2 ) J.Slowik, G.Borchardt, C.Kohler, R.Jeschar and R.Scholz: Steel Res., 61(1990), 302

3 ) T.Akiyama, H.Ohta, R.Takahashi, Y.Waseda and J.Yagi: ISIJ Int., 32(1992), 829.

4 ) M.Takeda, T.Onishi, S.Nakakubo and S.Fujimoto: Mater. Trans., 50(2009), 2242

5 ) R.Endo, T.Yagi, M.Ueda and M.Susa: ISIJ Int., 54(2014), 2084.

6 ) R.Taylor, C.M.Fowler and R.Rolls: Int. J. Thermophys., 1(1980), 225.

7 ) M.Li, M.Akoshima, R.Endo and M.Susa: CAMP-ISIJ, 29(2016), 720, CD-ROM.

8 ) V.Y.Zinovyev, V.F.Polev, S.G.Taluts, G.P.Zinovyeva and S.A.Ilinykh: Phys. Met. Metallogr., 61(1986), 85.
9 ) N.Shoji, Y.Haraguchi and M.Hariki: Proc. Natl. Heat Transf. Symp., 34(1997), 737.

10) T.Kato, Y.Haraguchi, M.Kawamoto and T.Watanabe: Tetsu-toHagané, 83(1997), 611.

11) R.Wendelstorf, K.-H.Spitzer and J.Wendelstorf: Int. J. Heat Mass Transf., 51(2008), 4892.

12) J.Lee: ISIJ Int., 49(2009), 1920.

13) H.Fukuda, N.Nakata, H.Kijima, T.Kuroki, A.Fujibayashi, Y.Takata and S.Hidaka: ISIJ Int., 56(2016), 628.

14) Y.Serizawa: CAMP-ISIJ, 30(2017), 63, CD-ROM

15) 新編 熱物性ハンドブック, 日本熱物性学会編, 養賢堂, 東京, (2008), 42.

16) JIS B 0601: 2013, Geometrical product specifications (GPS) - surface texture: profile method - terms, definitions and surface texture parameters.

17) M.Sugiyama: J. Met. Finish. Soc. Jpn., 10(1959), 323.

18) W.Sun, A.K.Tieu, Z.Jiang and C.Lu: J. Mater. Process. Technol., 155-156(2004), 1307.

19) L.S.Tong and Y.S.Tang: Boiling Heat Transfer and Two-Phase Flow 2nd edition, CRC Press Taylor \& Francis Group, New York, (1997), 52.

20) 理科年表，第79冊，国立天文台編，丸善，東京，(2006), 369 .

21) R.B.Bird, W.E.Stewart and E.N.Lightfoot: Transport Phenomena, John Wiley and Sons, New York, (1960), 283.

22) M.Li, M.Akoshima, R.Endo, M.Ueda and M.Susa: CAMP-ISIJ, 29(2016), 172, CD-ROM

23）新編 熱物性ハンドブック，日本熱物性学会編，養賢堂，東京， (2008), 209

24) A.-L.Biance, C.Clanet and D.Quere: Phys. Fluids, 15(2003), 1632.

25) N.R.Geraldi, G.McHale, B.B.Xu, G.G.Wells, L.E.Dodd, D.Wood and M.I.Newton: Mater. Lett., 176(2016), 205. 